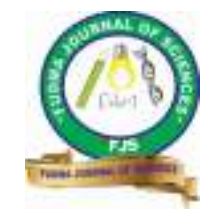

\title{
INTEGRATING DIGITAL ELEVATION MODEL, LANDUSE/LANDCOVER AND FLOOD FREQUENCY ANALYSIS: A DETERMINISTIC APPROACH TO FLOOD INUNDATION AND RISK MODELING OF MAKURDI ALONG ITS RIVER BENUE REACH
}

\author{
${ }^{* 1}$ Oyatayo, K. T., ${ }^{2}$ Ndabula, C., ${ }^{3}$ Jeb, D. N., ${ }^{2}$ Adamu, G. K., ${ }^{2}$ Jidauna, G. G. \\ ${ }^{1}$ Department of Geography, Kwararafa University, Wukari, Taraba State, Nigeria. \\ ${ }^{2}$ Department of Geography and Regional Planning, Federal University Dutsin- Ma, Nigeria \\ ${ }^{3}$ National Space Research and Development Agency, Abuja, Nigeria.
}

*Corresponding Author's email: kehindeoyatayo@gmail.com; 08067211169

\begin{abstract}
The study applied GIS techniques to integrate Digital Elevation Model (DEM), Landuse/Landcover (LULC) and flood frequency analyses to determine extent of flood hazard inundation of Makurdi town along its River Benue reach following extreme discharges and stage levels. Annual maximum stage and discharge data from 1914 to 2015 was analyzed using Gumbel's distribution to predict flood flow for different return periods (T): $5,10,25,50,75$, and 100. A goodness of fit test was conducted using Chi square statistics, which was insignificant indicating that River Benue at Makurdi flood flow fits the Gumbel distribution. Combining this result with DEM and classified LULC data, the GIS spatial analyst tool was used to estimate the areal extent of landuse that will be inundated per return period. The result shows extent of flood inundation based on current landuse pattern for the respective return periods of predicted extreme stage / discharge likely due to climate change to be as follows: bareland $\left(1.69,1.74,1.78,1.84,1.83,1.89 \mathrm{~km}^{2}\right)$; settlement/built-up $(5.38,5.50,5.63$, $\left.5.76,5.76,6.02 \mathrm{~km}^{2}\right)$; farmlands $\left(272.27,283.59,295.10,306.43,306.43\right.$, and $\left.317.49 \mathrm{~km}^{2}\right)$; Vegetation (91.56, 95.26, 98.78, 102.45, 102.48, and $\left.105.95 \mathrm{~km}^{2}\right)$; water bodies $\left(0.21,0.21,0.22,0.22,0.22\right.$, and $\left.0.22 \mathrm{~km}^{2}\right)$ and Wetlands $\left(44.14,45.80,47.48,30.36,49.42\right.$ and $\left.50.78 \mathrm{~km}^{2}\right)$. This reveals a general increase in the extent of flood inundation at progressive recurrence interval, and predicted rising extreme river stage heights / discharge except for the flood with 50 year recurrence interval. The study recommends that NEMA and Benue State Urban Development Board should provide flood warning systems and ensure full compliance of development guideline in the study area.
\end{abstract}

Keywords: Deterministic, River, Flood, frequency, Inundation, Modeling

\section{INTRODUCTION}

Flooding is one of the most common and widely distributed natural risks to life and property worldwide (Jeb, 2013). Flooding is one of the most widely spread, frequently occurring and most devastating natural hazards and accounts for approximately one third of all natural disasters in both developed and developing worlds (UNISDR, 2012). Flooding is also responsible for more than half of all related fatalities and a third of the economic loss from all natural catastrophes (White, 2000). The reason for this as observed by Agusomu (2013) lies in the widespread geographical distribution of river flood plains and low lying coast, together with their long standing attraction for human settlement.

Flooding is a natural process, which occurs over a river, stream and plains in a recurring manner depending on various factors such as landuse, rainfall, soil, slope etc. Flooding is due to a heavy or continuous rainfall exceeding the infiltration capacity of soil and the carrying capacity of rivers, streams, and coastal areas. This causes a river or stream to overflow over its banks onto adjacent lands. The frequency of flooding has increased over the past few decades causing havoc to life and property. $t$ is possible to predict the damage which would be caused by a flood, if it ever occurs. This can be done by generating inundation maps for different return periods and performing flood risk modeling (Luo et al., 2018). The damage caused by a flood varies from place to place as a variety of factors contribute towards flood risk. The land use and soil type play an important role in estimating how much of the rainfall is converted into runoff. In cities, the rapid urbanization plays an important role in contributing to increased runoff resulting from increased percentage of impervious area. The slope of the flood plain is also an important factor. If the flood plain has very low slope, it takes a longer time for the runoff to flow out and remains 
stagnant for a longer period. Flood modeling is carried out using spatial data such as satellite imagery, digital elevation model and soil map. In addition to spatial data, historical rainfall data and discharge data is required to generate the IDF curves and to calibrate the hydrologic model (Luo et al.,2018).

Throughout human history, there has been a constant endeavour to understand, assess and predict flood events and their impact. Flood inundation models are therefore developed to serve this purpose. As flooding accounts for a significant proportion of the total number of reported natural disasters occurring in the world, and over the last 30 years this proportion has been increasing (Freer et al., 2011), the development and application of flood inundation models and relevant research have become a global endeavour (Teng et al. 2017).

Over the past century, two groups of approaches to flood hazard inundation modeling have attracted the most attention (Teng et al., 2017): empirical methods such as measurements, surveys, remote sensing and statistical models evolved from these databased methods (e.g. Schumann et al., 2009; Smith, 1997); and hydrodynamic models. The latter include one-dimensional (1D) (e.g. Brunner, 2016; DHI, 2003), two-dimensional (2D) (DHI, 2012; Moulinec et al., 2011) and three-dimensional (3D) methodologies (Prakash et al., 2014; Vacondio et al., 2011) that simulate water movement by solving equations derived from applying physical laws to fluid motion with varying degrees of complexity. In recent years, a third group of approaches has been gaining increasing popularity for modeling very large floodplains (such as for national scale flood risk assessment) and data sparse regions. These models can be labeled as simplified conceptual models and are based on more modest representations of physical processes and have run times orders of magnitudes shorter than hydrodynamic models. They are particularly suitable for large study areas and/or stochastic modeling for probabilistic flood risk assessment (Teng et al. 2017).
Despite active research in the field, rapid and accurate flood modeling at high spatio-temporal resolutions remains a significant challenge in hydrologic and hydraulic studies. This is due to the complex and chaotic nature of flooding and uncertainty currently enduring in flood inundation modeling (Freer et al., 2011; Merz and Thieken, 2005; Teng et al., 2017). There has been improvement in flood predictions. For instance "Real-Time flood disaster prediction system by Applying Machine learning technique" by Ho Jun Keum et al., 2020. However, the extent of flood and its risk or potential damages is largely dependent on modelling approaches. The techniques used for flood inundation modeling are constantly evolving and modeling packages are always going through major changes, with some hugely improved and some discontinued. Therefore this study aim at integrating DEM and LULC to modeling river Benue at Makurdi river stage and discharge with a view to determine flood risk by modelling flood inundation extent and landuses that will be inundated should 5, 10, 25, 50, 75, 100 year flood occur in the study area, as this will enhance flood management.

\section{STUDY AREA}

\section{Location of the Study Area}

Makurdi Town is situated between latitude $07^{0} 43^{1} \mathrm{~N}$ to $07^{0} 45^{\prime}$ ' $\mathrm{N}$ and longitude $08^{0} 32^{\prime} \mathrm{E}$ to $08^{0} 38^{1} \mathrm{E}$. Makurdi Town is the capital city of Benue state, traversed by the Benue River from which the state's name was derived. The river splits the town into North and South banks respectively. Benue state is found in the Middle belt region of Nigeria. See Figure 3.1, for the location of Makurdi Town. It is bounded by Tarka Local Government Area (L.G.A) to the East, Guma to the North, Gwer - West to the West and Gwer to the South. Makurdi Town is made up of eleven council wards which include: Agan; Ankpa/ Wadata: Bar; Central South Mission; Fiidi, Mbalagh; Market Clark; Modern Market; North Bank I; North Bank II and Walmayo (Oyatayo et al., 2017). 


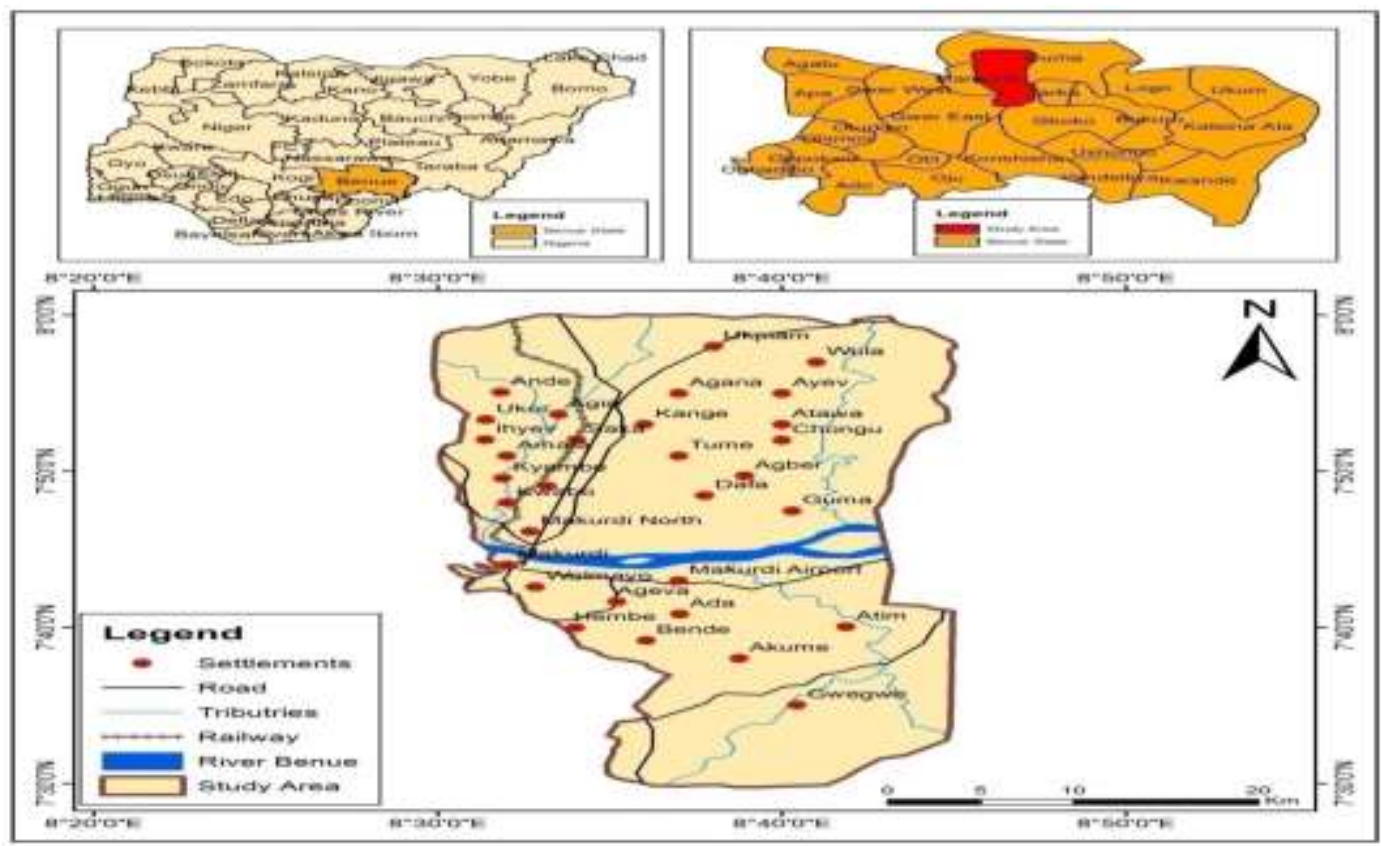

Figure 1: Location of the Study Area

Source: Adapted from the Administrative Map of Benue State

\section{Climate}

The climate of Makurdi Town is the tropic Aw type with alternating wet and dry seasons which are also hot and cool. The climate is characterized by southwest (SW) and northeast (NE) monsoons. The north south annual movement of intertropical discontinuity (ITD), the convergence zone, SW and NE monsoons, synoptic weather systems (such as thunder storms and squall lines) and topography influences rainfall distribution in the region (Abah, 2012).

Abah (2012) observed that the rainy season in Makurdi is from April to October, with rainfall amount ranging from $900 \mathrm{~mm}$ to $1200 \mathrm{~mm}$ with the heaviest rain in June and September which declines with increasing latitude. Annual rainfall in Makurdi Town is consistently high, with an average annual total of approximately $1173 \mathrm{~mm}$. The mean dates of onset and cessation of the rainy season are $15^{\text {th }}$ April and $14^{\text {th }}$ October respectively.

Tyubee (2005) identified three temperature periods that are being experienced in the study area which include:

i. The cool dry season, November- January (during the time of low sun)

ii. The hot dry season, February - April (just preceding the rain)

iii. The hot wet season, May - October (during the rain)

The temperatures are generally high, with mean annual temperatures of $32.5^{\circ} \mathrm{C}$. The atmospheric humidity varies with seasons from $80 \%$ during the wet season to $30 \%$ during the dry season. Wind speed is generally light to moderate except the squall lines that often gust at $66 \mathrm{~km} / \mathrm{h}$ (Benue State University Geography Dept. Field Work Manual, 2006).

\section{Relief and Drainage}

Makurdi Town is generally located in a plain that slopes up gently on either side of the river Benue at Makurdi. Thus, the elevation rises to the north about $154 \mathrm{~m}$ above sea level at Daudu, and to the south about $216 \mathrm{~m}$ above sea level at Ikpayongo (Benue State University Geography Department Field Work Manual, 2006).

The Benue River forms the major drainage channel in Makurdi Town. It flows east to west dividing the town into the north and south banks. Other drainage channels mostly first order streams and the tributaries of River Benue at Makurdi also drain the region. These include: Kpege, Adake, Asase, Idye, Urudu and Demekpe amongst others.

\section{Geology and Soils}

The geology of Makurdi Town consists mainly of sandstone and shale of the sedimentary formation of Benue Trough (BSU Geography Dept. Field Work Manual, 2006). The sandstone is divided into micaceous and feldsphatic sand-stones. The soils of the area are the tropical ferruginous soils that comprise of hydromorphics along flood plains and wetlands and lithosols of flood plains. The red ferrasols developed on sedimentary rocks are also found in the southern parts. The soils are a reflection of its parent materials developed by slope and climate.

The sandy nature of the topsoil makes infiltration easy which explains the usage of shallow wells in the area. The first aquifer is unconfined with precipitation infiltration through porous 
sandy environment as water source. The second aquifer also referred to as the semi-confined has the formation of highly consolidated and geologically made of shales intercalated with sandstones of coarse grains exhibiting larger pores.

\section{Vegetation}

The vegetation of Makurdi Town is characterized by a mixture of trees and grasses of the guinea savanna specie. However, human activities have depleted the natural vegetation due to the increase in urbanization; the vegetation today is that of derived vegetation with patches of natural tree species along river courses and reserves. The trees in the study area include fruit trees such as Anacardium Ocidentale (Cashew), Citrus X Sinesis (Orange) and Magnifera Indica (Mango) alongside other economic trees like Khaya Senegalensis (Mahogany), Triplochiton Scleroxylon(Obeche), Gmelina Arborea (Gmalina) and Milicia Excelsa (Iroko). The grasses are of a mixture of shrubs which are useful for animal grazing and medication respectively.

\section{Population}

Makurdi Town is inhabited by many tribes with a population of 519,051 (NPC, 1991) made up of 271, 051 males and 247, 910 females. The population of the town makes up $7.01 \%$ of the state's population. The town has a population density of 380 persons per square kilometer.

\section{Economic Activities}

There are several economic activities that are carried out in Makurdi Town. These include teaching due to several primary, post primary and tertiary institutions. Administrative work as it houses the state capital and the local government headquarters as well as Federal Secretariat. Banking services are also available with banking houses all over.

Trading is also carried out in the area due to the presence of markets; where there are shops with varying goods and services such as super markets, barbing and hair dressing saloons, computer centers, food vendors, meat shops, beer parlous, grinding mill operator, vulcanizers, automobile mechanics, street hawkers etc. also there are motor parks rendering transport services, as well as gas station.

Farming is practiced, most especially in the flood plains of River Benue. The crops produced include cereals and vegetables. Fishing activities also take place at the Benue River course as well as its tributaries. The presence of rest homes and sporting centers provide an avenue for hospitality and recreational activities.

\section{MATERIALS AND METHODS}

Types of Data

Data types used in this study are:

i. $\quad$ Flood characteristics (inundation area and depth)

$\begin{array}{ll}\text { ii. } & \text { landuse } \\ \text { iii. } & \text { Digital elevation } \\ \text { iv. } & \text { River stage } \\ \text { v. } & \text { Discharge } \\ \text { vi. } & \text { 2013 NigeriaSat-X satellite imagery }\end{array}$

\section{Sources of Data}

The listed data were sourced from both primary and secondary sources.

The primary sources of data

i. NigeriaSat-X (NX) satellite imagery of 2013 with spatial resolution of 22 meters was acquired from the National Space Research and Development Agency (NASRDA) Abuja.

ii. The Shuttle Radar Topography Mission (SRTM $30 \mathrm{~m}$ ) data were used to derive the DEM. of the study area.

Secondary sources of data

i. Annual Maximum Riverstage and discharge data for fifty four (54) years (1914-2015) were obtained from the National Inland Water Way Authority Headquarter, Lokoja, Kogi State, Nigeria and the Lower Benuer River Basin Development Authority, Makurdi, Benue State, Nigeria.

\section{GIS Techniques of Data Collection}

Satellite imagery of NigeriaSat X (2013) was scanned using Ao scanner and imported into AcGIS 10.3 environment for further GIS operations. All coordinate (X, Y) from GPS field mapping were entered into excel sheet, transferred to notepad and then ArcGIS 10.3 for plotting into maps.

\section{Geo-referencing}

Satellite Imagery of the study area were geo-referenced using ground control points (GCP's) obtained from GPS, using image to GPS techniques. A total of ten (10) GCPs were collected using GPS on the field. These points were distributed to ensure images are balanced on all the four axes and centralized at the center. The choice of images to GPS techniques is based on the fact that several data used were collected on the field using GPS and this reduced error during map composition and allowed points to fit in. The coordinates of these reference points were converted from geographic to UTM, in order to aid measurement later. Thus all images and were of the same datum, the same map projection and in the same ground coordinate system. ArcGIS 10.3 Software was used for geo-referencing all the needed data.

\section{Sub setting}

Coordinates of the study area were picked from the topographic map sheets covering the study area and register red to create a box which defines the sub-set made up of the study area using ArcGIS 10.3 software. Satellite imagery covering Makurdi Town were extracted from full scene of NigeriaSAT X. 


\section{Techniques of Data Analysis}

\section{LU/LC Data Processing.}

Supervised classification in the maximum likelihood classifier was adopted. The full scene of the satellite imagery covering the study area was loaded onto the computer hard disc ( $\mathrm{C}$ drive) and converted into ArcGIS 10.3 format. The combine process of visual image interpretation of tones/colours, patterns, shape, size, and texture of the satellite image processing were used to identify homogenous groups of pixels, which represent various land use classes of interest. This process as observed by Adeoye (2012) is commonly referred to as training sites because the spectral characteristics of those known areas were used to train the classification algorithm for eventual landuse classification of the image.

To validate the tonal values recorded on the satellite image with features obtained on ground and also to know what type of landuse was actually present, the study engaged in ground truthing as suggested by Adeoye (2012). Before the ground truthing, map of the study area was printed and was used as guide to locate and identify features both on ground and on the image data. The geographical locations of the identified features on the ground were clearly defined. These were used as training samples for supervised classification of the satellite data. Six (6) landuse were clearly identified during ground truthing, which were used to classify the image data. These are Water body, vegetation cover, farmland, wetland, buildup and bare surface. All classification results were delineated as polygons using on screen digitization with the aid of ArcGIS 10.3 software. Layers were topologised and saved as themes or coverage for use in map composition.

\section{Flood frequency analysis:}

Flood frequency analysis to determine return periods of extreme flood events using observed annual peak flow from discharge data was conducted. Gumbel distribution is a statistical method often used for predicting extreme hydrological events such as flooding (Jeb and Aggarwal, 2008). In this study, it was applied because:

i. Peak discharge data are homogenous and independent, hence, lack long term trends.

ii. The river is less regulated, hence, it is not significantly affected by reservoir operations and

iii. Flow data cover a relatively long record and is of goof quality
Peak level gauge data for fifty four (54) years (1914 to 2015) was used for the analysis. Gumbel defines floods as the largest of the 365 daily flows and the annual series of flood flows constitute a series of largest values flows. The equation is given as (Jebb and Aggarwal, 2008):

$$
\begin{aligned}
& \mathrm{S}_{\mathrm{T}}=\mathrm{X}+\mathrm{K} \times \mathrm{SDV}- \\
& \text { Where } \\
& \mathrm{S}_{\mathrm{T}}=\text { value of variate with a return period "T" } \\
& \mathrm{X}=\text { means of variate } \\
& \mathrm{SDV}=\text { standard deviation of the sample } \\
& \mathrm{K}=\text { Frequency factor expressed as } \\
& \mathrm{K}=\left(\mathrm{Y}_{\mathrm{t}}-\mathrm{Y}_{\mathrm{n}}\right) / \mathrm{S}_{\mathrm{n}} \\
& \mathrm{Y}_{\mathrm{t}}=\text { reduced variate expressed by: } \\
& \mathrm{Y}_{\mathrm{t}}=(\mathrm{LN} \times \mathrm{LN})(\mathrm{T} / \mathrm{T}-1) \\
& \text { Where } \\
& \mathrm{T}=\text { return period } \\
& \mathrm{Y}_{\mathrm{n}}=\text { reduced mean from table } \\
& \mathrm{S}_{\mathrm{n}} \text { reduced standard deviation from table }
\end{aligned}
$$

\section{I. $\quad$ Test of goodness of fit}

The Chi-square $(\chi 2)$ test was carried out to find goodness of fit between the measured and predicted flood flows. It was applied to test the hypothesis that the flood data fit Gumbel distribution.

\section{Flood Inundation Mapping}

i. A combination of recent data on floodplains such as LU/LC, river/flood stage, and DEM was used to predict future flood stages and likely impacts. Extreme value statistical model (Gumbel's distribution) was used to determine frequencies and different return period of flood hazards of certain magnitudes for 5, 10, 25, 50, 75 and 100 year flood. DEM maps of the study area were classified in ArcGIS 10.3 environment based on the above results of flood frequency analysis to obtain inundation extent per flood return period. These results using spatial analyst tool in ArcGIS 10.3 environment were overlaid on the landuse map of the study area to extract landuses that will be inundated per return period. Area of each land use inundated in 5, 10, 25, 50,75 and 100 year flood was calculated using spatial analyst tools (open attribute table - add field - field calculator). In all, flood inundation maps were produced highlighting landuses that will be inundated and the extent of inundation per return period.All procedures in the methodology are shown in figure 2. 


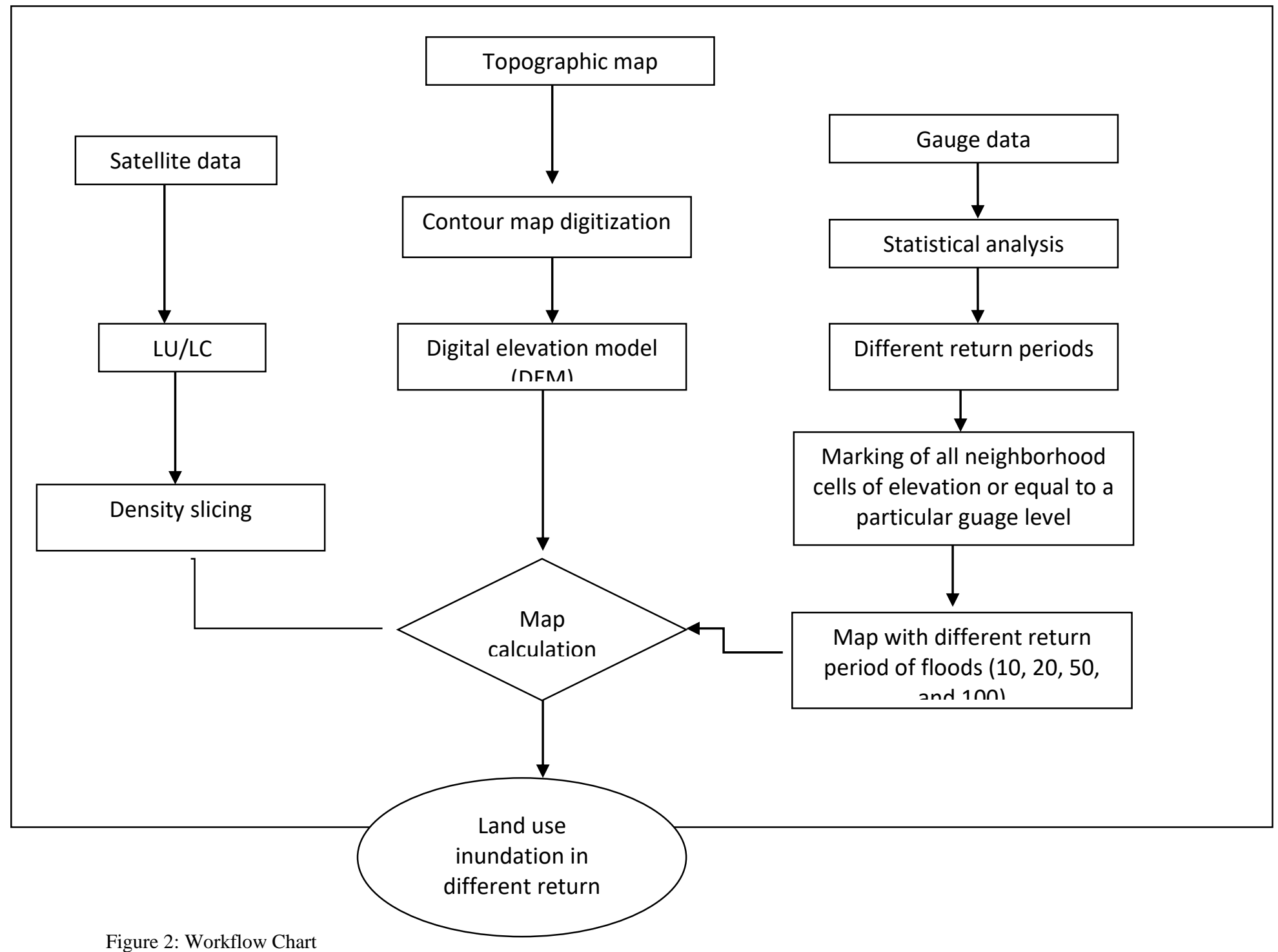

Figure 2: Workflow Chart

Source: Adopted from Jebb and Aggarwal (2009)

i. $\quad$ Area of Landuse that will be Inundated per Return Period

The result of the analysis of LU/LC, flood frequency and DEM was integrated in ArcGIS 10.3 environment to achieve this. An ArcGIS 10.3 command was used to derive the area of inundation per return period from the DEM if the areas lie below the height of the river stage of the given return period. The total inundated area generated from the DEM was extracted from the classified landcover maps by the process of extraction by mask found in the spatial analyst tool of ArcGIS 10.3 software. The DEM and the LU/LC maps were combined to create the total flooded area per return period. The total areas of the landuse classes were determined and then for each individual land use type. The total land use map was combined with the flood map. After which the following were calculated:

ii. The percentage of the total area inundated

iii. The areas inundated by water for each land use classes.

\section{RESULTS AND DISCUSSION}

Flood Frequency Analysis of River Benue at Makurdi

The objective of frequency analysis of hydrologic data is to relate the magnitude of extreme events to their frequency of occurrence using probability distribution. If the probability of a particular flood magnitude being equaled or exceeded is known, then risk can be assessed. Table 1 shows the results of modeled river stage and discharge of $5,10,25,50,75$ and 100 year recurrence interval of floods in River Benue at Makurdi. The river stage and magnitude for floods with 5, 10, 25, 50, 75 and 100year recurrence interval are 11.00 meter/ $12,979 \mathrm{~m}^{3} / \mathrm{sec}$, 12.02 meter $/ 12,980 \mathrm{~m}^{3} / \mathrm{sec}, 13.32$ meter $/ 12,980 \mathrm{~m}^{3} / \mathrm{sec}, 14.29$ meter/ $12,981 \mathrm{~m}^{3} / \mathrm{sec}, 14.85$ meter $/ 12,981 \mathrm{~m}^{3} / \mathrm{sec}$ and 15.22 meter/12,982 $\mathrm{m}^{3} / \mathrm{sec}$ respectively. In Makurdi Town, floods with 100, 75, 50, 25, 10 and 5yearrecurrence interval will have $1 \%, 1.3 \%, 2 \%, 4 \%, 10 \%$ and $20 \%$ chance of occurrence in any given year. The modeled river stage and discharge values of 5 , 
$10,25,50,75$ and 100 year recurrence interval were derived by substituting the relevant values of Gumbel frequency factor $(\mathrm{K})$, mean and standard deviation (STD) as shown in Table 1 in to the Gumbel distribution $\mathrm{S}_{\mathrm{T}}=\mathrm{X}+\mathrm{K} \times \mathrm{SD}$.

Table 1: Modeled Water Level and Magnitude

\begin{tabular}{llllllllll}
\hline S/N & $\begin{array}{l}\text { Recurrence } \\
\text { Interval }\end{array}$ & $\begin{array}{l}\text { Exceed } \\
\text { ance } \\
\text { probabil } \\
\text { ity } \\
\text { percent }\end{array}$ & $\begin{array}{l}\text { Frequen } \\
\text { cy }\end{array}$ & $\begin{array}{l}\text { Factor } \\
(\mathrm{K})\end{array}$ & $\begin{array}{l}\text { Mean } \\
\text { Stage }\end{array}$ & STD & $\begin{array}{l}\text { Stage } \\
\text { Level } \\
(\mathrm{m})\end{array}$ & $\begin{array}{l}\text { Mean } \\
\text { Magni } \\
\text { tude } \\
\left(\mathrm{m}^{3} / \mathrm{sec}\right)\end{array}$ & $\begin{array}{l}\text { STD } \\
\text { Magnitude } \\
\left(\mathrm{m}^{3} / \mathrm{sec}\right)\end{array}$ \\
\hline 1 & 5 & 20 & 0.813 & 9.7 & 1.6 & 12.11 & 10,345 & 2,633 & 12,979 \\
2 & 10 & 10 & 1.455 & 9.7 & 1.6 & 12.76 & 10,345 & 2,633 & 12,980 \\
3 & 25 & 4 & 2.267 & 9.7 & 1.6 & 13.57 & 10,345 & 2,633 & 12,980 \\
4 & 50 & 2 & 2.869 & 9.7 & 1.6 & 14.16 & 10,345 & 2,633 & 12,981 \\
5 & 75 & 1.3 & 3.219 & 9.7 & 1.6 & 14.59 & 10,345 & 2,633 & 12,981 \\
6 & 100 & 1 & 3.467 & 9.7 & 1.6 & 14.77 & 10,345 & 2,633 & 12,982 \\
\hline
\end{tabular}

Source: Oyatayo, 2017

The relevant values for $\mathrm{K}$ were derived from Gumbel $\mathrm{K}$ factor distribution as shown in table 2, while the overall mean and STD of the river stage and discharge were calculated from the fifty four (54) years annual maximum discharge and stage data of river Benue at Makurdi.

The frequency or probability of a flood usually is described by assigning a recurrence interval to the flood at each gauging station. This is accomplished by statistically evaluating long term annual peak stream flows at a station (Jeb and Aggarwal, 2008). Flood predictions are made on the basis of recurrence interval values projected over long time intervals. Gumbel distribution as adopted in this study is a statistical method often used for predicting extreme hydrological events such as flooding (Jeb and Aggarwal, 2008). Peak level gauge data for fifty four (54) years (1914 to 2015) as shown in table 3 was used for the analysis. Gumbel defines floods as the largest of the 365 daily flows and the annual series of flood flows constitute a series of largest values flows. The equation for Gumbel distribution is given as $\mathrm{ST}=\mathrm{X}+\mathrm{K} \times \mathrm{SD}$.

The annual maximum stageand discharge data of river Benue at Makurdi shows that the highest water level of 12.60 meter with magnitude of $17,700 \mathrm{~m}^{3} / \mathrm{sec}$ was recorded in the hydrological year 2012 and the least 3.99 meter with magnitude of $318 \mathrm{~m} 3 / \mathrm{sec}$ was recorded in the hydrological year 1916. Table 1 shows that as the modeled river stage and magnitude increases, the recurrence interval increases, while exceedence probability reduces. This goes to show that floods with high magnitude are not frequently experienced in Makurdi Town. It is however observed that such floods have high risk when they occur. The hydrological implication of this finding is that floods with 100 , 75 and 50 year recurrance interval in Makurdi Town, has lower probability of exceedance when they occur and have far reaching impact on the environment. This is so because such flood flows have higher stage levels and magnitude and will be far reaching in low lying areas with gentle slope in the study area. This confirms the works of Oyatayo et al., (2017) in Donga River Basin, Shakirudeen and Saheed (2014) in Lower Ogun River Basin whose research on flood frequency analysis reported that flood flows with higher recurrence interval and low exceedance probability have high river stages and magnitudes and thus posits that such flood flows have high risk when they occur. Such flood flows have high risk because they have higher river stages /magnitude and inundate more land areas.

Flood frequency analysis of this nature is a multi-dimensional tool used in the assessment of water resource potential as well as both hydrologic and hydraulic measure that must be integrated in the engineering construction of structures that concern a defined water body. In addition, this measure is a tool of necessity to ascertain the extent of inundation based on hydrologic data. It provides the data frame for inundation area mapping as well as for the assessment of flood hazard and risk within an area (Shakirudeen and Saheed, 2014 cited in Oyatayo et al., 2017). Okonofua and Ogbeifun (2013) reported that since man does a lot of activities on the flood plain, it has become important for him to protect it against flood. Some of the structures used by man to control flood are levees, reservoir and channel improvement. For an economic and efficient design of these measures, flood has been estimated with some level of accuracy. Once an estimate of maximum or peak flood which occur in a particular site can be estimated, an ideal solution can then be proffered by a hydraulic Engineer. 


\section{Flood Frequency: Test of Goodness to Fit}

It is of great importance to confirm if the observed flood data collected in Makurdi drainage basin follows the Gumbel's distribution or not. The non-parametric statistic used to ascertain the goodness to fit is the Chi-square statistic. As observed by Shakirudeen and Saheed (2014) the Chi square distribution is an excellent measure of goodness to fit owing to its inherent statistical properties for test of association and homogeneity. Using Chi square distribution, the following null hypothesis was tested as shown in Table 2:

$\mathrm{H}_{0}$ : There is no significant difference between observed and expected flood flow data in River Benue at Makurdi

Table 2: Chi Squeare Computation of Goodness to Fit for Gumbel Distribution

\begin{tabular}{lcccccc}
\hline S/N & $\begin{array}{c}\text { Return } \\
\text { Period }\end{array}$ & $\begin{array}{c}\text { Observed } \\
\text { Gauge } \\
\text { height }(\mathrm{m})\end{array}$ & $\begin{array}{c}\text { Expected } \\
\text { Gauge } \\
\text { height }(\mathrm{m})\end{array}$ & $(\mathrm{O}-\mathrm{E})$ & $(\mathrm{O}-\mathrm{E})^{2}$ & $(\mathrm{O}-\mathrm{E})^{2} / \mathrm{E}$ \\
\hline 1 & 5 & 11.00 & 13.43 & -2.43 & 5.9 & 0.44 \\
2 & 10 & 12.02 & 13.43 & -1.43 & 2.05 & 0.15 \\
3 & 25 & 13.32 & 13.43 & -0.13 & 0.017 & 0.0013 \\
4 & 50 & 14.29 & 13.43 & 0.84 & 0.71 & 0.053 \\
5 & 75 & 14.85 & 13.43 & 1.37 & 1.88 & 0.14 \\
6 & 100 & 15.22 & 13.43 & 1.79 & 3.2 & 0.24 \\
\hline
\end{tabular}

1.0243

Decision Rule: The Chi square calculated and tabulated values at 0.05 level of significance and 5 degree of freedom goes thus:

Calculated Chi square value $=1.0243$

Tabulated Chi square value $=11.07$

From the foregoing, the Null hypothesis is accepted; the Chi square test revealed a satisfactory fit between observed and estimated flood flows. This indicates that the flood flow data fit Gumbel distribution and hence, Gumbel distribution can be used to predict the frequency of floods of river Benue at Makurdi. This corroborates the findings of Ehiorobo and Uso (2014), that conducted a research on flood frequency analysis in the lower river Niger basin at Onitsha Bridge head and presented a result of measured and expected flood flows showing no differences, hence, a goodness to fit of the Gumbel distribution.
Landuses that will be inundated by $5,10,25,50,75$ and 100 year flood in Makurdi Town

Presented here are flood inundation maps for 5, 10, 25, 50, 75 and 100 year recurrance interval in Makurdi Town. Figures 3 8 and Table 3 shows the landuses that will be inundated per recurrence interval in Makurdi Town. Figure 3 and Table 3 shows that in Makurdi Town $1.69 \mathrm{~km}^{2}$ of bare surface, $5.38 \mathrm{~km}^{2}$ of settlement, $272.27 \mathrm{~km}^{2}$ of farmland, $91.56 \mathrm{~km}^{2}$ of vegetation, $0.21 \mathrm{~km}^{2}$ of water body and $44.14 \mathrm{~km}^{2}$ of wetland will be inundated should a flood with 5 year recurrence interval occur. A total of $415.25 \mathrm{~km}^{2}$ of landuses in Makurdi Town will be inundated should a flood with magnitude of $12,979 \mathrm{~m}^{3} / \mathrm{sec}$ and 5 year recurrence interval occur. 


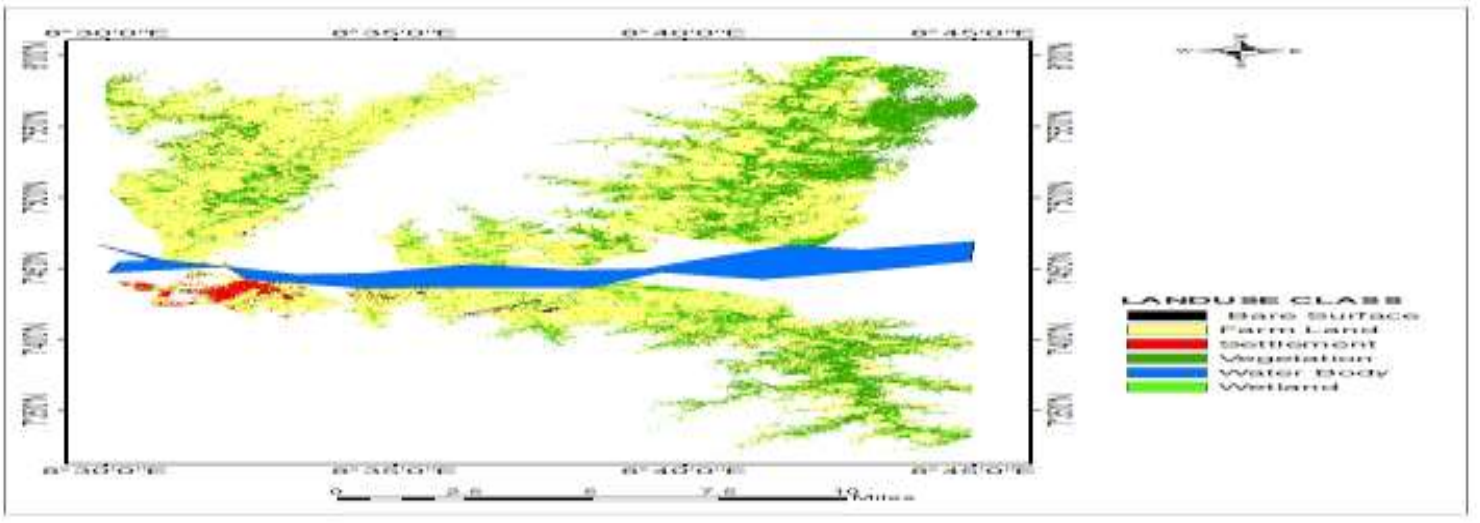

Figure 3: Landuse Inundated by a Flood with 5 Year Recurrence Interval

Table 3: Landuses Inundated per Recurrence Interval in Makurdi Town

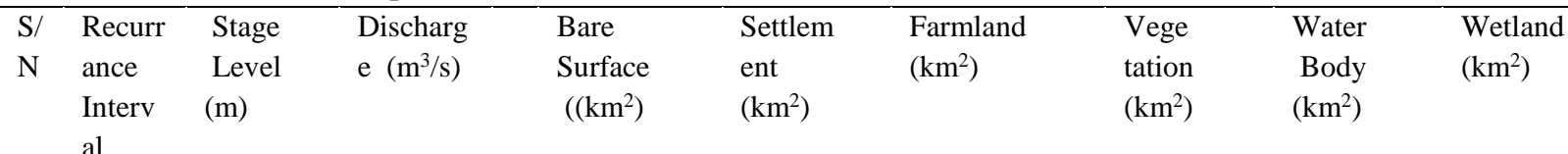

\begin{tabular}{llllllllll}
\hline 1 & 5 & 12.11 & 12,979 & 1.69 & 5.38 & 272.27 & 91.56 & 0.21 & 44.14 \\
2 & 10 & 12.76 & 12,980 & 1.74 & 5.50 & 283.59 & 95.26 & 0.21 & 45.80 \\
3 & 25 & 13.57 & 12,980 & 1.78 & 5.63 & 295.10 & 98.78 & 0.22 & 47.48 \\
4 & 50 & 14.16 & 12,981 & 1.84 & 5.76 & 306.43 & 102.45 & 0.22 & 30.36 \\
5 & 75 & 14.59 & 12,981 & 1.83 & 5.76 & 306.43 & 102.48 & 0.22 & 49.42 \\
6 & 100 & 14.77 & 12,982 & 1.89 & 6.02 & 317.49 & 105.95 & 0.22 & 50.78
\end{tabular}

Source: Oyatayo, 2017

Figure 4 and Table 3 shows that in Makurdi Town, $1.74 \mathrm{~km}^{2}$ of bare surface, $5.50 \mathrm{~km}^{2}$ of settlement, $283.59 \mathrm{~km}^{2}$ of farmland, 95.26 $\mathrm{km}^{2}$ of vegetation, $0.21 \mathrm{~km}^{2}$ of water body and $45.80 \mathrm{~km}^{2}$ of wetland will be inundated should a flood with 10 year recurrence interval occur. A total of $432.09 \mathrm{~km}^{2}$ of landuses in Makurdi Town will be inundated should a flood with magnitude of 12,980 $\mathrm{m}^{3} / \mathrm{sec}$ and 10 year recurrence interval occur.

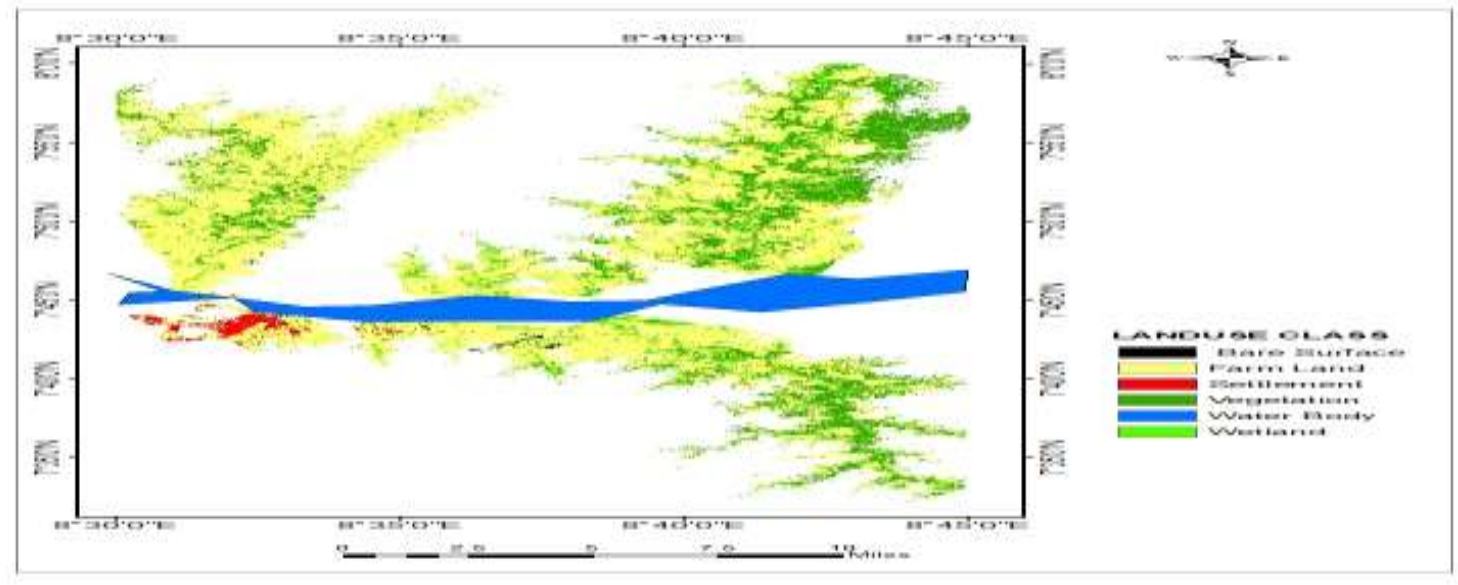

Figure 4: Landuse Inundated by a Flood with 10 Year Recurrence Interval 
Figure 5 and Table 3 shows that in Makurdi Town $1.78 \mathrm{~km}^{2}$ of bare surface, $5.63 \mathrm{~km}^{2}$ of settlement, $295.10 \mathrm{~km}^{2}$ of farmland, 98.78 $\mathrm{km}^{2}$ of vegetation, $0.22 \mathrm{~km}^{2}$ of water body and $47.48 \mathrm{~km}^{2}$ of wetland will be inundated should a flood with 25 year recurrence interval occur. A total of $448.98 \mathrm{~km}^{2}$ of landuses in Makurdi Town will be inundated should a flood with magnitude of 12,980 $\mathrm{m}^{3} / \mathrm{sec}$ and 25 year recurrence interval occur.

Figure 6 and Table 3 shows that in Makurdi Town $1.84 \mathrm{~km}^{2}$ of bare surface, $5.76 \mathrm{~km}^{2}$ of settlement, $306.43 \mathrm{~km}^{2}$ of farmland, 102.45 $\mathrm{km}^{2}$ of vegetation, $0.22 \mathrm{~km}^{2}$ of water body and $30.36 \mathrm{~km}^{2}$ of wetland will be inundated should a flood with 50 year recurrence interval occur. A total of $321.05 \mathrm{~km}^{2}$ of landuses in Makurdi Town will be inundated should a flood with magnitude of 12,981 $\mathrm{m}^{3} / \mathrm{sec}$ and 50 year recurrence interval occur.

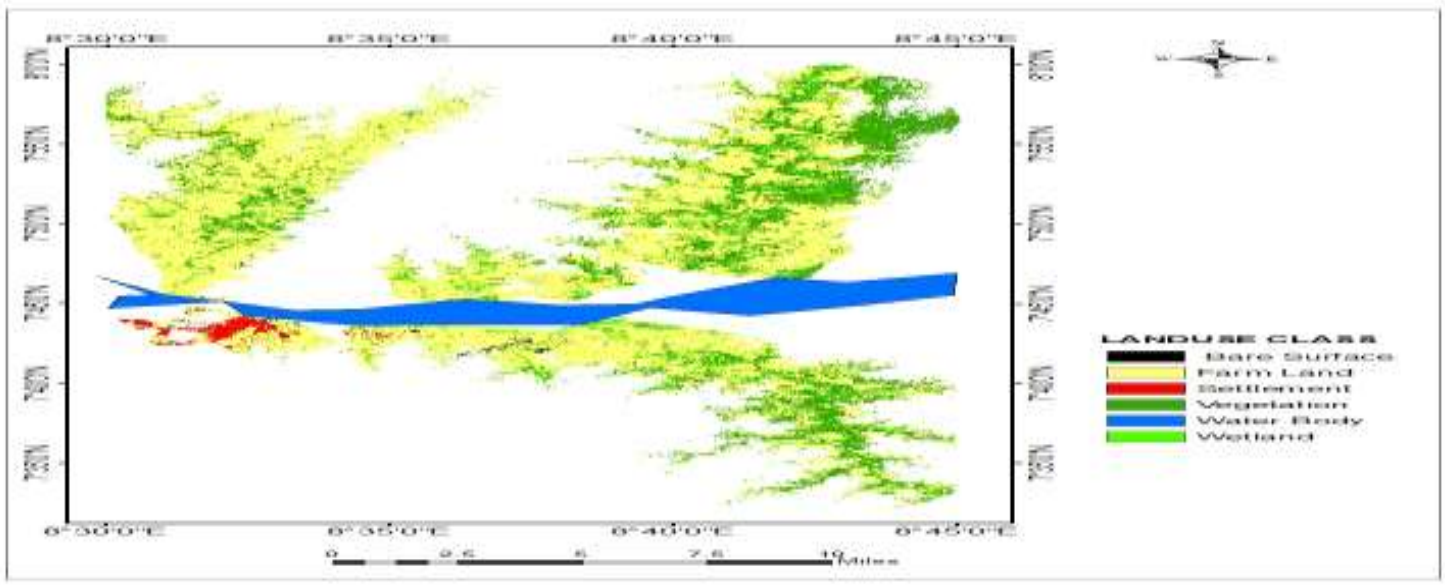

Figure 5: Landuses Inundated in a Flood with 25 Year Recurrence Interval

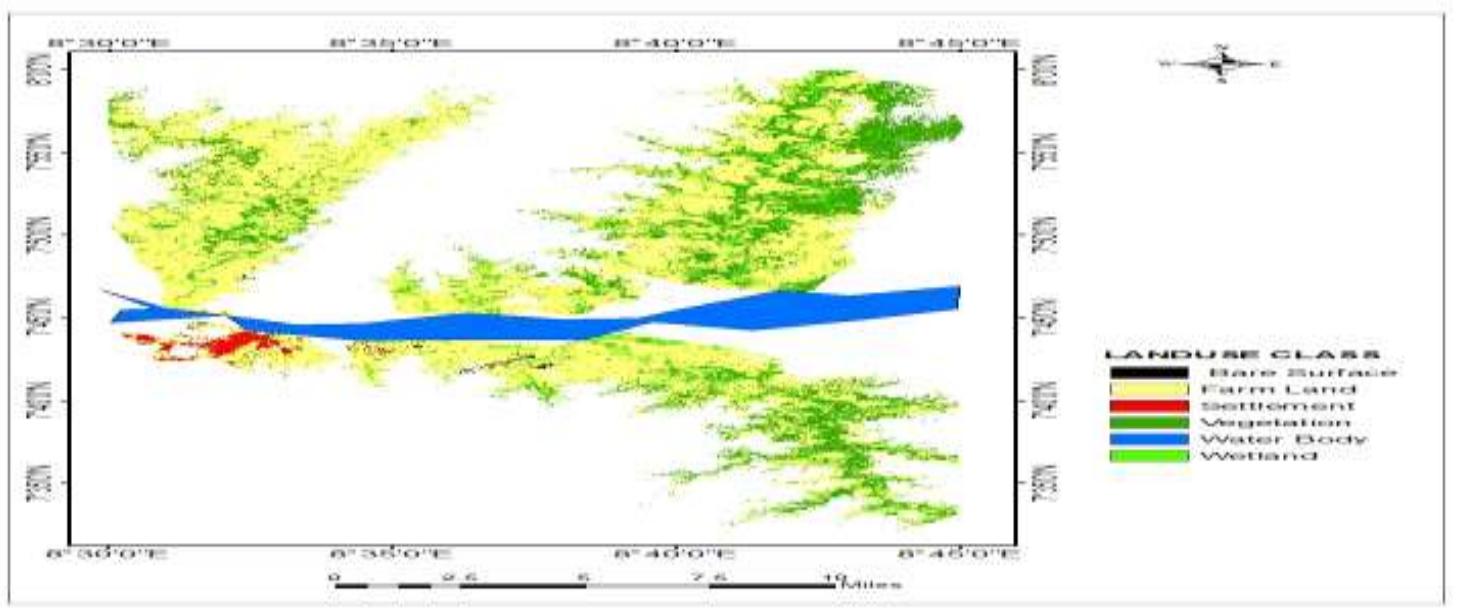

Figure 6: Landuses Inundated in a Flood with 50 Year Recurrence Interval

Figure 7 and Table 3 shows that in Makurdi Town $1.83 \mathrm{~km}^{2}$ of bare surface, $5.76 \mathrm{~km}^{2}$ of settlement, $306.43 \mathrm{~km}^{2}$ of farmland, 102.48 $\mathrm{km}^{2}$ of vegetation, $0.22 \mathrm{~km}^{2}$ of water body and $49.42 \mathrm{~km}^{2}$ of wetland will be inundated should a flood with 75 year recurrence interval occur. A total

of $466.13 \mathrm{~km}^{2}$ of landuses in Makurdi Town will be inundated should a flood with magnitude of $12,981 \mathrm{~m}^{3} / \mathrm{sec}$ and 75 year recurrence interval occur. 


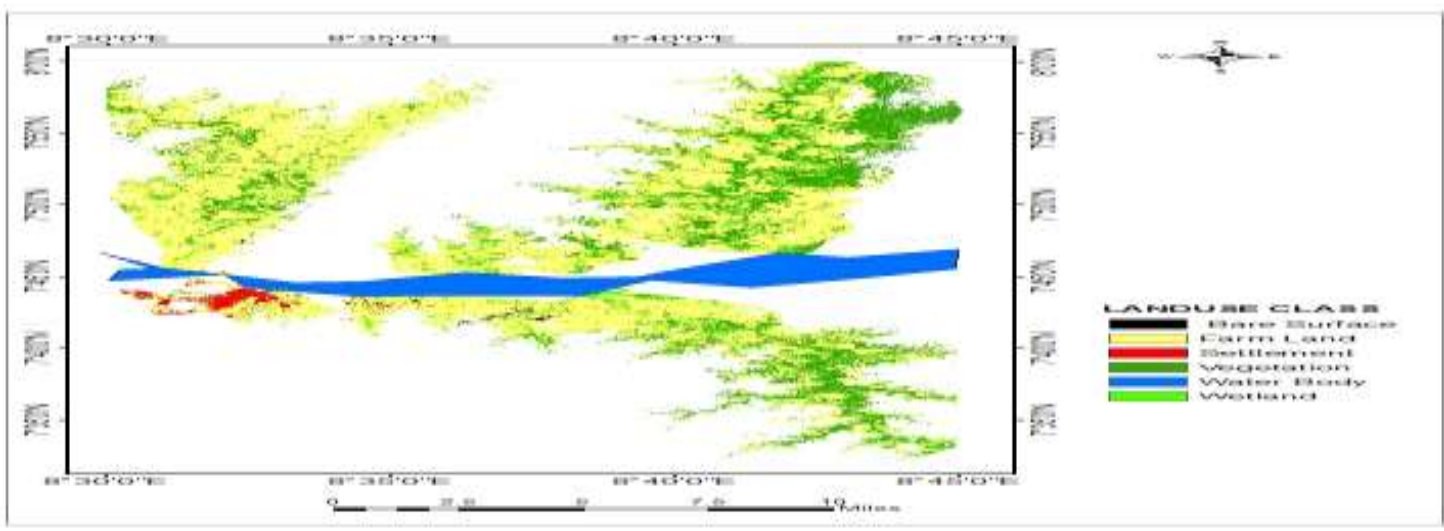

Figure 7: Landuses Inundated in a Flood with 75 Year Recurrence Interval

Figure 8 and Table 3 shows that in Makurdi Town, $1.89 \mathrm{~km}^{2}$ of bare surface, $6.02 \mathrm{~km}^{2}$ of settlement, $317.49 \mathrm{~km}{ }^{2}$ of farmland, $105.95 \mathrm{~km}^{2}$ of vegetation, $0.22 \mathrm{~km}^{2}$ of water body and $50.78 \mathrm{~km}^{2}$ of wetland will be inundated should a flood with 100 year recurrence interval occur.

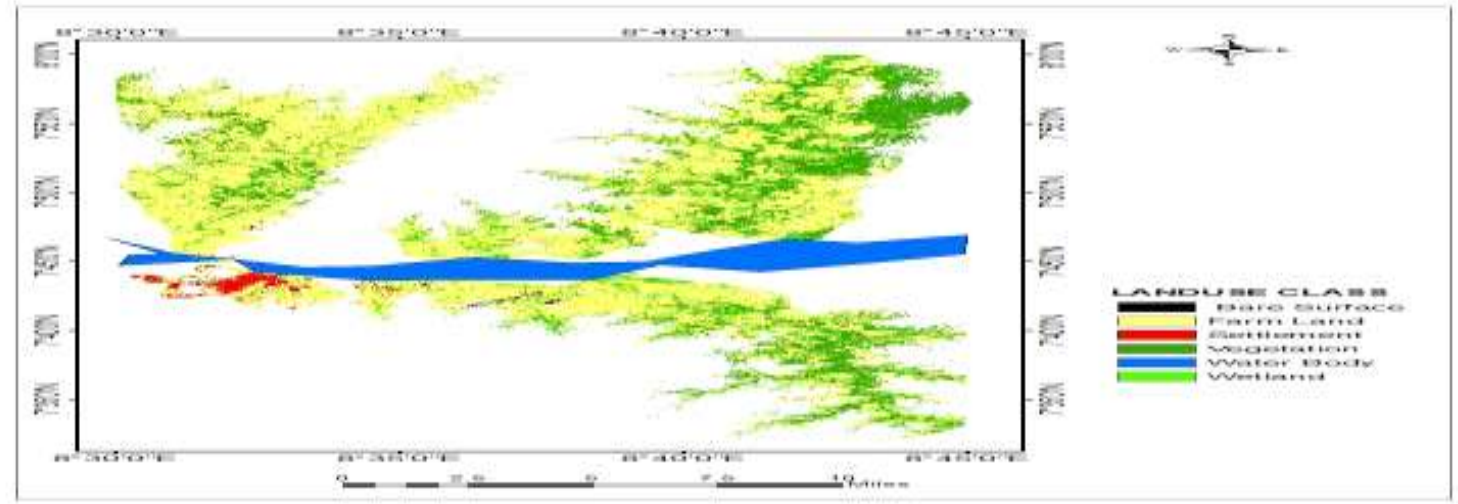

Figure 8: Landuses Inundated in a Flood with 100 Year Recurrence Interval

A total of $482.33 \mathrm{~km}^{2}$ of landuses in Makurdi Town will be inundated should a flood with magnitude of $12,982 \mathrm{~m}^{3} / \mathrm{sec}$ and 100 year recurrence interval occur.

It is worthy of note that the results of flood hazard inundation mapping obtained for Makurdi Town revealed a general increase in the area extent of flood inundation with increase in recurrence interval except for the flood with 50 year recurrence interval. In a flood with 5-year recurrence interval, the area extent of flood inundation would be approximately 415.25 $\mathrm{km}^{2}(38.85 \%), 432.09 \mathrm{~km}^{2}(40.43 \%)$ in a flood with 10 -year recurrence interval, $448.98 \mathrm{~km}^{2}(42.01 \%)$ in a flood with $25 \mathrm{year}$ recurrence interval, $321.05 \mathrm{~km}^{2}(30.04 \%)$ in a flood with 50 -year recurrence interval, $466.13 \mathrm{~km}^{2}(43.62 \%)$ in a flood with 75 year recurrence interval and $482.33 \mathrm{~km}^{2}(45.13 \%)$ in a flood with 100year recurrence interval. There were no significant changes in areas that would be flooded in the settlement and Water Body landuse. Although the water body shows no general increase in area, it means that such water body will be completely inundated in the 5-year return period.
The constant extent of water body inundation refers to the river channel which is already inundated and changes in channel width geomorphologically are not expected to change significantly over shorter period of time as used in this study. For this flood inundation analysis shows that for all return periods, farmland will be more inundated than other landuses because most of the immediate land to the river is currently used as farmlands. Builtup inundation shows that if the present limits of built-up are maintained, flood inundation over various return periods will not differ significantly. However, if built-up expands into the farmland areas, the patterns may change with more builtup inundated. Floodplain encroachment by builtup will imply more built-up inundation extent. Urban expansion especially floodplain encroachment will alter this pattern of flood inundation; with shift to increase on built-up.

Using the derived estimations from Table 3, the spatial trend of inundation could be deduced based on the annual land area that 
is anticipated to be inundated per recurrence interval. The results present a simple relation that the higher the recurrence interval of the flood, the higher the annual land area that is anticipated to be inundated. This is because flood flows with higher return periods are associated with higher river stages and magnitude, which makes them more devastating even though they occur with least frequency. Also in Makurdi Town, this manifest as a result of the increase in the elevation on the north central and south western part of Makurdi Town in addition to the reduction in the water surface modeled for these land areas. Basically, inundation of these areas is based on the modeled river stage. Also, the floodplains adjoining the south bank of river Benue at Makurdi are prone to flooding coupled with the low elevation of the area and heavy presence of impervious surface in the area. This is similar to the findings of Shakirudeen and Saheed (2014) who conducted a study on flood frequency analysis and inundation mapping of Lower Ogun river basin and reported spatial trend of inundation manifesting as a consequence of the increase in elevation on the northern part of the basin in addition to the reduction in the water surface modeled for the northern part of the basin. This is also similar to the findings of Jebb and Aggarwal (2008) that conducted a study on flood inundation hazard modeling of river Kaduna using Remote sensing and GIS. They reported a general increase in the areas flooded as the flood return period increases from a 5-year return period to the 100 -year return period. This they attribute partly to differences in slope across the study area and the fact that floods with higher return perods have higher river stages and magnitude, which makes them more devastating even though they occur with least frequency.

It is worthy of note that $38.85 \%$ to $45.13 \%$ of the total land in Makurdi Town is anticipated to be inundated. The implication of this kind of inundation outcome as observed by Shakirudeen and Saheed (2014) is huge when compared to the nature and extent of anthropogenic activities and the importance of the floodplain in regulating the natural hydrological fluxes in a basin. The likelihood of exposure to flood risk might be higher going by the fact that road infrastructure, electricity lines and other hydrologic engineering structures within the basin are connected to human activities that are located on the floodplain.Flood inundation mapping of this nature provides flood risk maps that represents the characteristics of a hypothetical flood graphically from a synthesis of past flood events. With sufficient long term and accurate records, flood extents drawn from the empirical results become very powerful prediction tools because the flood risk map is often a map of more than one flood event (Shakirudeen and Saheed, 2014). Flood inundation maps are therefore the basic tools and starting points of regional flood intervention policy (Jeb and Aggarwal, 2008). For the public, flood inundation maps can help to increase overall public awareness on flood risk and hazards. Flood inundation mappingwhen combined with reliable flood forecasts, can provide local authorities with important information for emergency flood response and mitigation.

\section{SUMMARY}

In this study flood frequency analysis using Gumbel distribution was conducted to arrive at modeled river stage and discharge for $5,10,25,50,75$ and 100 year flood in Makurdi town. This result alongside DEM and the classified landuse/landcover data were imported into GIS environment and analysed to produce flood extent and landuses that would be inundated in 5, 10, 25, 50, 75 and 100 year flood. Based on this, in Makurdi North west, settlement was found to be the largest extent of inundation in the 5 year (short term) return period. This means that most of the buildup areas of Makurdi North west are vulnerable in the most frequent flood occurrence. The implication of this on lives and properties leaves the risk to flooding to be very high.

While in Makurdi South west, farmlands are the most inundated in the 5 year flood. Literature has shown that Makurdi town is witnessing high rate of urbanization. Future conversion of farmland to residential and commercial landuse in Makurdi South West should be done with utmost landuse planning. This is because the 5 year flood in Makurdi Town is the flood with the highest probability of occurrence and farmland is expected to be the dominant landuse to be inundated should this flood occur. These built-up that have encroached on these farmlands will be inundated because they have encroached on farmlands that are highly susceptible to flood.

\section{CONCLUSION}

Makurdi town is the capital of Benue State with rapid urban development and land conversion. It is also situated at the lower and extensive floodplain segment of the river Benue at Makurdi. The low lying topography of the area alongside the perennial high river stage and discharge due to accumulation of runoff/discharge over an extensive basin lead to the flood inundation modeling. This flood inundation and flood return period analyses approach used in this study provided detail understanding of the spatial (areal extent) and temporal (frequency) of flood under certain extreme rainfall/discharge events especially under this climate change dispensation. The predictive spatio-temporal flood pattern helps for short, medium and long term landuse planning and management of flooding especially builtup or settlement landuse in the study area which showed increasing extent with increasing river stage/discharge under increasing return periods $(5,10,25,5075$ and 100yrs). This implies that sprawling most be seriously forestalled or controlled in Makurdi town.

\section{RECOMMENDATION}

The landuse based flood frequency inundation model map can be used by Benue State Urban Development Board for the development of a landuse zonation and building standard control. This also helps to provide specification of flood mitigation, control and management measures. For instance in Makurdi Northwest, damage to life and property in the builtup can be controlled by structural measures such as dykes and 
embarkment, while for the Makurdi southwest, construction of Dam as a structural measure can reduce flood damage, which also coincide with the highest factor of the perception of structural measures that can control or reduce flood damage in the study area.

\section{REFERENCES}

Abah, R.C. (2012). Causes of seasonal flooding in floodplains: A case of Makurdi, Northern Nigeria. International Journal of Environmental studies.1-9.

Adeoye, N. O., Ayanlade, A., and Babatimehin, O. (2009). Climate Change and Menase of floods in Nigerian cities: Socioeconomic implications. The free library, science and Technology, Advance in Natural and Applied Science.

Agusomu, T. D. (2013). The perception of and Response to floods in the Niger Delta Basin of Nigeria. Unpublished Ph.D. Thesis, Department of Geography and Planning, University of Jos.

Brunner, C.W. (2016). HEC-RAS river analysis system-users manual version 5.0. US Army Corps of engineers Institute for water resources, hydrologic engineering center (HEC),p 962.

BSU Geography Department, field work manual (2006). Local field work manual for geography students, Benue State University, Makurdi.

DHI (2012).MIKE 21-2D modeling of coast and sea.DHI water and environment PTY ltd.

Ehiorobo, J.O. and Uso. N.O. (2014).Flood frequency analysis in the Lower River Niger Basin at Onitsha Bridge head. Journal of Engineering Research, volume 19, number 1:33-44.

Freer, J., Beven, K.J., Neal, J., Schumann, G., Hall, J., Bates, P., 2011. Flood Risk and Uncertainty. Risk and Uncertainty Assessment for Natural Hazards, Cambridge, UK, pp. 190-233.

Gumbel, E. J. (1941). The return period of flood flows. Annals of mathematical statistics, 12 (2): 163-190.

Jeb, D. N. (2013). Application of Geo-information Science in Flood risk Analysis in Kaduna Metropolis, Kaduna, Nigeria. Unpublished Ph.D. Thesis submitted to the Department of Geography, Ahmadu Bello University, Zaria.

Jeb, D. N., and Aggarwal, S. P. (2008). Flood inundation hazard modeling of river Kaduna using Remote sensing and GIS. Journal of applied sciences research, 43(12): 1822-1833.

Luo, P., Mu, D., Xue, H., Ngo-Duc, Dang-Dinh, T., Takara, K., Nover, D.and Geofrey, S. (2018).Flood inundation assessment for the Hanoi Central Area, Vietnam under historical and extreme rainfall conditions. Scientific Reports, 8:1-11.

Merz, B. and Thieken, A.H. (2005). Separating natural and epistemic uncertainty in flood frequency analysis. J. Hydrol. 309 (1-4), 114-132.

Moulinec, C., Denis, C., Pham, C.T., Rouge, D. and Hervouet, J.M. (2011). TELEMAC: an efficient hydrodynamics suite for massively parallel architectures. Comput. Fluids 51 (1): 30-34. Okonofua, S. and Ogbeifun, P. (2013).Flood frequency analysis of Osse River using Gumbel distribution. Civil and Environmental Research, volume 3, number 10: 55-60

Oyatayo, K. T., Kushi, D. Z., Jidauna, G. G., and Ndabula, C. (2017).Gumbel's flood frequency probability analysis of river Donga, Taraba state, Nigeria. Journal of Geography and Development, 7 (1): 766-782.

Prakash, M., Rochauge, K. and Cleary, P.W. (2014). Modeling the impact of dam failure scenarios on flood inundation using SPH. Applied Mathematical Model, 38(23): 5515-5534.

Schumann, G., Bates, P.D., Horritt, M.S., Matgen, P., Pappenberger, F. (2009). Progress in integration of remote sensing derived flood extent and stage data and hydraulic models. Rev. Geophys. 47 (4), RG400.

Shakirudeen, O. and Saheed, A.R. (2014). Flood Frequency Analysis and Inundation Mapping of Lower Ogun River Basin. Journal of Water Resource and Hydraulic Engineering, 3 (3): 48-59.

Smith, L.C. (1997). Satellite remote sensing of river inundation area, stage, and discharge: a review. Hydrol. Process. 11 (10), 1427-1439.

Teng, A.B., Jakeman, A.J., Vaze, B.J., Croke, B.F.W., Dutta, D. and Kim,S. (2018). Flood inundation modeling: A review of methods, recent advances and uncertainty analysis. Environmental Modelling \& Software, 90:201-216.

Tyubee, B.T. (2005). Spatial organization of daily rainfall in the middle Belt of Nigeria. The Benue Valley Journal of interdisciplinary Studies. 4 (1).

UNISDR (2012). United Nations International Strategy for Disaster reduction, available at: http://www.unisdr.org (last access: 31 March 2012), 2012.

Vacondio, R., Rogers, B., Stansby, P. and Mignosa, P. (2011). SPH modeling of shallow flow with open boundaries for practical flood simulation. J. Hydraul. Eng. 138 (6): 530 -541. White, W.R. (2000). Water in Rivers: flooding, a contribution to the world water Vision, IAHR, UK.

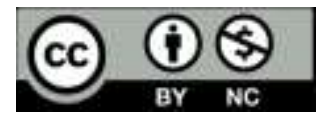

(C)2021 This is an Open Access article distributed under the terms of the Creative Commons Attribution 4.0 International license viewed via https://creativecommons.org/licenses/by/4.0/ which permits unrestricted use, distribution, and reproduction in any medium, provided the original work is cited appropriately. 